Q

\section{QALAA HOLDINGS SCHOLARSHIP FOUNDATION (QHSF)}

Qalaa Holdings Scholarship Foundation, P.O. Box: 29, Cairo, EG, 11516, Egypt

Tel: (20) 227945553

Fax: (20) 227925849

Email: info@qalaascholarships.org, info@citadelscholarships.org Website: www.citadelscholarships.org/index.html

In 2007, Qalaa Holdings established the Qalaa Holdings Scholarship Foundation (QHSF, previously known as the Citadel Capital Scholarship Foundation) as its flagship CSR project. The firm has endowed the Foundation to grant academic scholarships to talented young Egyptian men and women interested in pursuing Master's degrees and $\mathrm{PhDs}$ at international universities.

\section{Citadel Capital Scholarship}

Subjects: Eligibility criteria and application procedures are all explained on the website. CCSF is only funding Master's level degrees at the moment.

Purpose: The Citadel Capital Scholarship Foundation was created in 2007 , out of a strong will to contribute to national development through creating high caliber professionals to help enhance Egypt's growth in all sectors.

Eligibility: Students from Egypt can apply for this Citadel Capital Scholarship.

Level of Study: Postgraduate

Type: Scholarship

Value: US $\$ 50,000$

Closing Date: The application deadline is January 15th to April 30th of every year

\section{QUEEN ELISABETH INTERNATIONAL MUSIC COMPETITION OF BELGIUM}

20 rue aux Laines, B-1000 Brussels, Belgium

Tel: (32) 22134050

Fax: (32) 25143297

Email: info@qeimc.be

Website: www.qeimc.be

Contact: Secretariat

The Queen Elisabeth International Music Competition of Belgium is a non-profit association, located in Brussels, whose principal aim is to organize major international competitions for music virtuosos. In this way, the competition participates in the Belgian and international music world, and gives its support to young musicians.

\section{Queen Elisabeth International Music Competition of \\ Belgium \\ Subjects: Music (piano, voice, violin and cello).}

Purpose: To provide career support for young pianists, singers, violinists and cellists.

Eligibility: Open to musicians of any nationality who are at least

17 years of age and not older than 30 years for violin, piano, singing and cellists. The competition is made up of a first round, a semi-final and a final round.

Level of Study: Unrestricted

Type: Competition

Value: Prizes, awards and certificates along with cash prizes will be awarded

Frequency: Annual

Country of Study: Any country

No. of awards offered: 12

Application Procedure: Applicants must obtain an application form from the Secretariat of the Competition or via the website.

Closing Date: January 10th

Funding: Private

No. of applicants last year: Unrestricted

Additional Information: There are no master classes with jury members.

\section{QUEEN MARGARET UNIVERSITY}

Queen Margaret University Drive, Musselburgh, Edinburgh,

EH21 6UU, United Kingdom

Tel: (44) 1314740000

Fax: (44) 1314740001

Email: rilo@qmu.ac.uk

Website: www.qmuc.ac.uk

Contact: Professor Anthony Cohen, Principal

Queen Margaret University provides vocationally relevant education in business and enterprise; drama and creative industries; health, including international health; and social sciences, media and communication. Its internationally recognized research activity informs our teaching. With around 4,500 students, our small size allows us to offer students a highly supportive environment.

\section{SAAS Postgraduate Students' Allowances Scheme (PSAS)}

Subjects: Cultural management programmes, art therapy, audiology and international health scheme.

Purpose: International Health Scheme.

Eligibility: U.K. and EU nationals living in Scotland on the relevant date (conditions apply).

Level of Study: Postgraduate

Value: Up to $£ 3,400$ for full-time students and up to $£ 1,700$ for parttime students

Length of Study: 2 years, full-time

Frequency: Annual

Study Establishment: Queen Margaret University College

Country of Study: United Kingdom

No. of awards offered: 4

Application Procedure: Applicants must complete an application

and send it to the SAAS, once nominated by the institution.

Closing Date: March 31st

Funding: Government

Contributor: Students Awards Agency for Scotland (SAAS)

No. of awards given last year: 2

Additional Information: Students cannot apply directly to the SAAS.

They must have accepted an offer of a place and be nominated by the institution.

For further information contact:

Tel: 44 (0)1314740000

Email: rilo@qmu.ac.uk

\section{QUEEN MARY, UNIVERSITY OF LONDON}

Admissions and Research Student Office, Mile End Road, London, E1 4NS, England

Tel: (44) 02078825555

Fax: (44) 02078825588

Email: admissions@qmul.ac.uk

Website: www.qmul.ac.uk

Contact: Mr Peter Smith, Admissions Assistant

Queen Mary is the fourth largest college in the University of London. Located on an attractive campus, it has more than 8,000 students studying in four faculties plus St Bartholomew's and the Royal London School of Medicine and Dentistry. Of these, more than 1,600 are pursuing postgraduate courses or undertaking research.

\section{CCLS LLM Paris Partial Scholarship}

Subjects: Law.

Eligibility: The offer is open both to Home/EU and international students and applications will be assessed on the basis of academic merit. Students holding either a full or part time offer may apply for the partial scholarship. For detailed information, please visit website.

Level of Study: Postgraduate

Type: Scholarship

Value: Sum of $£ 5,000$ will be deducted from tuition fees payable to Queen Mary

Country of Study: United Kingdom

Application Procedure: The mode of applying is by post or email. 
Closing Date: November 4th

Contributor: The Centre for Commercial Law Studies (CCLS) within the School of Law at Queen Mary University of London

Additional Information: Phone interviews for shortlisted candidates will be held on November 8th with the successful candidate being contacted the following week.

\section{Herchel Smith Scholarship in Intellectual Property}

Subjects: The Herchel Smith PhD Scholarship Programme recognizes and supports exceptional full-time students who show the potential to make an outstanding contribution to intellectual property law. This programme supports $\mathrm{PhD}$ students in intellectual property law and those working at the intersection of intellectual property law and other areas of sciences and humanities.

Eligibility: New PhD students undertaking full-time research in the area of Intellectual Property (IP) can apply for a Herchel Smith Scholarship to start in the academic year. Open to both UK and non-EU applicants.

Type: Scholarship

Value: The award will cover all tuition fees whether at the Home/EU rate or the overseas rate. In addition, an award of around $£ 15,000$ per year (reviewed annually) will be paid to the recipient on a monthly basis throughout the calendar year starting from September Length of Study: 3 years

Frequency: Annual

Application Procedure: Submit online application at www.law.qmul. ac.uk/postgraduate/funding/phd-ip/index.html. You should make sure that you read all the information in Entry Requirements and How to Apply section of the $\mathrm{PhD}$ page (www.law.qmul.ac.uk/postgraduate/ courses/law/139691.html) before completing the online application process.

Closing Date: June 1st

For further information contact:

School of Law

Email: g.skehan@qmul.ac.uk

Contact: Mr Gareth Skehan, PhD Admissions Administrator

\section{Queen Mary, University of London Research \\ Studentships}

Subjects: Arts, sciences, engineering, social sciences, law, medicine and dentistry.

Purpose: To provide the opportunity for full-time research leading towards an MPhil or PhD.

Eligibility: Candidates will normally be expected to have a good first degree and a Masters degree in Politics, International Relations, or a related subject.

Level of Study: Research

Type: Studentship

Value: $£ 16,052$

Length of Study: 3 years full-time subject to a satisfactory academic report

Frequency: Annual

Study Establishment: Queen Mary University of London

Country of Study: United Kingdom

No. of awards offered: $20+$

Application Procedure: Applicants must contact the Admission and Recruitment Office for further application details.

Closing Date: January 31st

Funding: Government

No. of awards given last year: 30

No. of applicants last year: $200+$

Additional Information: These studentships are not available to existing Queen Mary research students.

\section{THE QUEEN'S NURSING INSTITUTE}

3 Albemarle Way, London, EC1V 4RQ, England Tel: (44) 02075491400

Fax: (44) 02074901269

Email: rosemary.cook@qni.org.uk

Website: www.qni.org.uk

Contact: Anne Pearson, Practice Development Manager
The Queen's Nursing Institute works to support and develop new and best nursing practice and innovation in primary care. Through this support we want to ensure that patients receive the highest standard of nursing in the community. Primary care has always been the highest priority and the Queen's Nursing Institute firmly believes in working in partnership with nurses to achieve its overall objectives.

\section{The Queen's Nursing Institute Fund for Innovation and Leadership}

Subjects: Implementation of good practice, or a project or an idea, within the community.

Purpose: The QNI Fund for Innovation provides professional and financial support to community nurses wishing to undertake projects which improve services and/or develop practice in the care of patients at home and in the community.

Eligibility: Must be a qualified community nurse.

Level of Study: Graduate, Postgraduate, Professional development Type: Grant

Value: Up to UK£5,000

Length of Study: 1 year

Frequency: Annual

Study Establishment: The Queen's Nursing Institute

Country of Study: United Kingdom

No. of awards offered: Varies, usually $6-10$

Application Procedure: Applicants must submit an application proposal and a curriculum vitae.

Closing Date: October 17th (Please check the website for the details) Funding: Private

Contributor: National Gardens Scheme

No. of awards given last year: 12

\section{QUEENSLAND UNIVERSITY OF TECHNOLOGY}

\author{
2 George Street, Brisbane City QLD 4000, Australia \\ Tel: +61731382000 \\ Email: research.enquiries@qut.edu.au \\ Website: www.rsc.qut.edu.au
}

The Queensland University of Technology abbreviated as QUT, is a public research university located in the urban coastal city of Brisbane, Queensland, Australia. QUT provides a career-oriented education which helps graduates find employment in their chosen career, in an environment which uses the latest technology to make learning stimulating and enjoyable. It provides information for students, staff and visitors about the resources of the University, its facilities and processes.

\section{APAI Scholarships within Integrative Biology}

Subjects: Plant science and biological sciences.

Eligibility: Open to citizens of Australia or permanent residents

having Honours 1 Degree or equivalent.

Level of Study: Postgraduate

Type: Scholarship

Value: Australian $\$ 25,627$

Length of Study: 3 years

Frequency: Annual

No. of awards offered: 2

Application Procedure: Check website for further details.

Closing Date: March 2nd

For further information contact:

School of Integrative Biology

Email: susanne.schmidt@uq.edu.au

Contact: Dr Susanne Schmidt, Senior Lecturer

\section{ARC APAI - Alternative Engine Technologies}

Subjects: Engineering and technology.

Purpose: The multidisciplinary nature of the project will provide the student with a significant intellectual challenge, to assimilate the required background research and to integrate this knowledge to achieve the aims of the current project. 
Eligibility: Open to citizens of Australia or New Zealand or permanent residents who have achieved Honours 1 or equivalent, or Honours 2a or equivalent.

Level of Study: Postdoctorate, Postgraduate

Type: Scholarship

Value: Australian $\$ 26,140$ per year

Length of Study: 3 years

Frequency: Annual

Country of Study: Australia

No. of awards offered: 1

Application Procedure: Check website for further details.

Closing Date: September 28th

Additional Information: Please check website for more details.

For further information contact:

Queensland University of Technology, School of Engineering

Systems, GPO Box 2434, Brisbane, QLD, 4001, Australia

Tel: (61) 731385174

Email: rong.situ@qut.edu.au

Website: www.rsc.qut.edu.au/future/scholarships/APAI.jsp

Contact: Dr Rong Situ

\section{Faculty of Education International Student Scholarship}

Subjects: Education.

Eligibility: You can apply for this scholarship if you're an international student and you: have received an offer to study a Master of

Education (EU70) (majoring in early years, inclusive education, general studies, leadership and management, or TESOL) are commencing your studies in the upcoming semester.

Level of Study: Postgraduate

Type: Scholarship

Value: $\$ 5,000$

No. of awards offered: 1 scholarship to students starting in Semester 1, and 1 scholarship to students starting in Semester 2

Closing Date: February 3rd

Additional Information: For more details, visit https://www.qut.edu. au/study/fees-and-scholarships/scholarships-and-prizes/faculty-ofeducation-international-student-scholarship.

\section{Gerard Connolly Prize in Law}

\section{Subjects: Law.}

Purpose: Scholarships are available for pursuing undergraduate, postgraduate coursework and postgraduate research degree level at QUT.

Eligibility: Applicants must be an undergraduate, postgraduate or research law and justice student who was enroled during the current academic year. Applicant should have contributed to the community through volunteer or charitable work such as community legal centres, or organizations such as the Queensland Cancer Fund and the Royal Blind Society.

Type: Scholarship

Value: Total offer is of $\$ 550$

Frequency: Annual

Country of Study: Australia

Application Procedure: The mode of applying is by post, in person and electronically.

Closing Date: October 14th

Institute of Health and Biomedical Innovation Awards

Subjects: Biomedical engineering, engineering and technology,

medical and health sciences or physical sciences.

Purpose: To support living expenses.

Eligibility: Open for citizens of Australia or permanent residents who have achieved Honours 1 or equivalent, or Honours 2a or equivalent. Level of Study: Doctorate, Postgraduate

Type: Award

Value: Australian $\$ 36,140$
Length of Study: 2 years (Masters) or 3 years (PhD)

Frequency: Annual

Country of Study: Australia

No. of awards offered: 4

Application Procedure: Check website for further details.

Closing Date: October 12th

For further information contact:

Queensland University of Technology, IHBI, QUT, GPO Box 2434,

Brisbane, QLD, 4001, Australia

Tel: (61) 731386056

Fax: (61) 731386039

Email: s.winn@qut.edu.au

Website: www.rsc.qut.edu.au/studentsstaff/scholarships/

arw domestic.jsp

Contact: Stella Winn, Research Services Manager

\section{International Postgraduate Research Scholarship at Queensland University of Technology}

Subjects: Business, creative industries, education, health, law, science and engineering and environments.

Eligibility: Applicants should be applying to study a PhD, masters by research, or professional doctorate. They should have a minimum first class honours or equivalent. Applicants should not have previously held an Australian Government-funded research scholarship for more than 6 months.

Type: Postgraduate scholarships

Value: It includes tuition fees and health-cover costs for the selected candidate and his/her dependents. Selected candidate may also be considered for an Australian Postgraduate Award living allowance scholarship

Country of Study: Australia

Application Procedure: Applicants should apply for admission to QUT during the Annual Scholarship Round. An indication should be provided on the application for admission that one wishes to be considered for a scholarship.

Closing Date: September 30th

\section{Postgraduate Research Award for Australian and International Students}

Subjects: Business, creative industries, education, health, law, science and engineering, health and biomedical innovation, and future environments.

Purpose: To support students of exceptional research potential with QUT PRAs.

Eligibility: You must have a first-class honours $(\mathrm{H} 1)$ or equivalent If you're not sure if your qualifications are equivalent to first-class honous, check our guidelines for determining honours equivalence (at https://cms.qut.edu.au/_data/assets/pdf_file/0005/275477/honoursequivalence-research-applications.pdf), and be accepted into a PhD or professional doctorate at QUT

Level of Study: Postgraduate, Research

Type: Research award

Value: You'll receive a living allowance, indexed annually $(\$ 25,849$ in current year). The scholarship is tax exempt for full-time students, and is to support living costs for up to 3 years for doctoral students. International students will also receive an accompanying QUT Higher Degree Research Tuition Fee Sponsorship. You can also apply for a $\$ 1,520$ relocation allowance (domestic students only)

No. of awards offered: Varies from year to year Application Procedure: Please check website for detailed information in how to apply.

Closing Date: September 30th

Additional Information: Please check at www.qut.edu.au/study/ fees-and-scholarships/scholarships-and-prizes/qut-postgraduateresearch-award-qutpra for more information. 